\title{
Discovery of a black smoker vent field and vent fauna at the Arctic Mid-Ocean Ridge
}

\author{
Rolf B. Pedersen ${ }^{1,2}$, Hans Tore Rapp ${ }^{1,3}$, Ingunn H. Thorseth ${ }^{1,2}$, Marvin D. Lilley ${ }^{4}$, Fernando J.A.S. Barriga ${ }^{5}$, \\ Tamara Baumberger $^{6}$, Kristin Flesland ${ }^{1,2}$, Rita Fonseca ${ }^{5,7}$, Gretchen L. Früh-Green ${ }^{7}$ \& Steffen L. Jorgensen ${ }^{1,3}$
}

The Arctic Mid-Ocean Ridge (AMOR) represents one of the most slow-spreading ridge systems on Earth. Previous attempts to locate hydrothermal vent fields and unravel the nature of venting, as well as the provenance of vent fauna at this northern and insular termination of the global ridge system, have been unsuccessful. Here, we report the first discovery of a black smoker vent field at the AMOR. The field is located on the crest of an axial volcanic ridge $(A \vee R)$ and is associated with an unusually large hydrothermal deposit, which documents that extensive venting and long-lived hydrothermal systems exist at ultraslow-spreading ridges, despite their strongly reduced volcanic activity. The vent field hosts a distinct vent fauna that differs from the fauna to the south along the Mid-Atlantic Ridge. The novel vent fauna seems to have developed by local specialization and by migration of fauna from cold seeps and the Pacific.

\footnotetext{
${ }^{1}$ Centre for Geobiology, University of Bergen, 5007 Bergen, Norway. ${ }^{2}$ Department of Earth Science, University of Bergen, 5007 Bergen, Norway. ${ }^{3}$ Department of Biology, University of Bergen, 5007 Bergen, Norway. ${ }^{4}$ School of Oceanography, University of Washington, Seattle, $98195-7940$ Washington, USA. ${ }^{5}$ University of Lisbon, Faculty of Sciences, Creminer LA-ISR-Centro de Recursos Minerais, 1749-016 Lisboa, Portugal. ${ }^{6}$ ETH Zurich, Institute for Geochemistry and Petrology, 8092 Zurich, Switzerland. ${ }^{7}$ Department of Geosciences, School of Sciences and Technology, University of Évora, 7000 Évora, Portugal. Correspondence and requests for materials should be addressed to R.B.P. (email: rolf.pedersen@geo.uib.no).
} 
$\mathrm{T}$ he discovery of the Trans-Atlantic Geotraverse (TAG) hydrothermal field on the Mid-Atlantic Ridge in $1985^{1}$ demonstrated that hydrothermal activity is not only restricted to ridges spreading at fast rates, but also occurs along parts of the global ridge system that are spreading at a slow rate $(20-55 \mathrm{~mm}$ per year). At spreading rates below $20 \mathrm{~mm}$ per year, volcanic activity decreases to a level where the crust becomes thinner than normal and may even disappear-resulting in the upper mantle becoming exposed at the seafloor ${ }^{2,3}$. The magmatic heat budget at these ultraslow-spreading ridges is one order of magnitude below that at fast-spreading ridges ${ }^{4}$, and the extent that hydrothermal activity could be sustained at such ridges has been questioned. However, oceanographic surveys along parts of the South-west Indian Ridge and the Gakkel Ridge have shown that venting is more common than expected ${ }^{5-7}$. Further advances in our understanding of venting at ultraslow-spreading rates have been awaiting the discovery of specific venting sites and the sampling of fluids being released there.

Chemoautotrophic primary production at submarine hot springs supports endemic vent fauna. The fauna at Pacific vent sites is distinct from that at Atlantic sites, and the discovery of a vent field at the East Indian Ridge revealed a mixed Atlantic and Pacific provenance ${ }^{8}$. This has been proposed to support the hypothesis of an along-ridge migration using active vent sites as stepping stones ${ }^{9-11}$. In the Atlantic, Iceland forms a barrier for northward along-ridge migration. Until now, four vent sites have been studied in the north of Iceland ${ }^{12}$, but these are all dominated by local bathyal species ${ }^{13}$. However, these vent sites are located at the southern part of the AMOR, which is influenced by the Icelandic hot spot, and therefore they are unusually shallow. As local bathyal species are known to replace vent endemic fauna at shallow water depths ${ }^{14}$, exploration of the deeper parts of the AMOR to the north was necessary to obtain conclusive information about the nature of vent fauna within the isolated Arctic Ocean.

Here, we report the discovery of a black smoker vent field located at the AMOR. The field is associated with a large hydrothermal deposit and it hosts distinct fauna, which differs from that of the Mid-Atlantic Ridge.

\section{Results}

Geology of the Loki's Castle vent field. In July 2008, we discovered a deep vent field 'Loki's Castle' on the AMOR at $73^{\circ} 30^{\prime} \mathrm{N}$ and $8^{\circ} \mathrm{E}$ (Fig. 1), and revisited it in 2009 and 2010 for additional sampling. The vent field is located where the Mohns Ridge passes into the Knipovich Ridge through a sharp northward bend in the direction of the spreading axis. The venting occurs near the summit of an AVR that is around $30 \mathrm{~km}$ long, and the vent field is here associated with a 50-100-m deep rift that runs along the crest of the volcano (Fig. 2). The field is composed of four active black smoker chimneys, up to $13 \mathrm{~m}$ tall, at the top of a mound of hydrothermal sulphide deposits. Venting of $310-320^{\circ} \mathrm{C}$ black smoker fluids occurs at two sites that are around $150 \mathrm{~m}$ apart. These venting areas seem to be located above two north-east-striking, semi-parallel normal faults that define the north-western margin of the rift. Two 20-30-m high sulphide mounds have developed around the venting areas. The mounds are each 150-200 $\mathrm{m}$ across at the base where they coalesce into a large composite mound. This is comparable in size to the TAGmound, which is one of the largest hydrothermal mounds known to date in the deep ocean ${ }^{15}$. The main sulphide assemblage in chimneys consists of sphalerite, pyrite and pyrrhotite, with minor amounts of chalcopyrite. Some sulphide-poor samples are mostly composed of anhydrite, gypsum and talc. A gravity core taken from the mound sampled more $\mathrm{Cu}$-rich hydrothermal deposits $0.5 \mathrm{~m}$ subsurface, indicating that higher temperature venting had occurred in the past. An area with low-temperature venting was located at the eastern flank of the mound. There, a dense field of small $(<1 \mathrm{~m})$ chimneys composed primarily of barite is associated with bacterial mats and a rich vent fauna. Clear, shimmering $\sim 20^{\circ} \mathrm{C}$ fluids are locally seen to emanate from this low-temperature field.

Vent fluid compositions. The Loki's Castle high-temperature vent fluids (Table 1) have high volatile concentrations $\left(\mathrm{CO}_{2}=26.0\right.$, $\mathrm{CH}_{4}=15.5, \mathrm{H}_{2}=5.5$; all in $\left.\mathrm{mmol} \mathrm{kg}^{-1}\right)$. The $\mathrm{CH}_{4}$ values are among the highest reported from a volcanic-hosted field. The high $\mathrm{CH}_{4}$ and $\mathrm{H}_{2}$ values could indicate interaction with ultramafic rocks ${ }^{16,17}$. However, the ultramafic systems studied to date exhibit higher concentrations of $\mathrm{H}_{2}$ (up to $15-16 \mathrm{mmol} \mathrm{kg}^{-1}$ ) and lower $\mathrm{CH}_{4} / \mathrm{H}_{2}$ ratios ${ }^{16-18}$. The Loki's Castle fluids are further characterized by a $\mathrm{pH}$ of 5.5, endmember (EM) hydrogen sulphide $\left(\mathrm{H}_{2} \mathrm{~S}\right)$ content up to $4.7 \mathrm{mmol} \mathrm{kg}^{-1}$ and very high ammonium $\left(\mathrm{NH}_{4}^{+}\right)$concentrations $\left(6.1 \mathrm{mmol} \mathrm{kg}^{-1}\right)$. The high $\mathrm{CH}_{4}$ values together with the elevated $\mathrm{NH}_{4}^{+}$concentrations point to a sedimentary influence. Significant sediment accumulations are not present at the volcanic ridge hosting the field, but the distal parts of a sedimentary fan are present $5 \mathrm{~km}$ to the south-east (Fig. 2). Sediments at depth below the volcano seems as the most likely source of the anomalous volatile contents.

Vent fauna. Loki's Castle harbours a rich, locally adapted and specialized, deep-water vent fauna. Dense fields of siboglinid tube worms (Sclerolinum contortum) on the sulphide mound (Fig. 3a,b) are among the organisms that dominate in terms of abundance and biomass. These are normally found on cold seeps and are common at the nearby Haakon Mosby Mud Volcano and the Nyegga cold seeps. Molecular markers support the morphological identification, and the hot vent and cold seep individuals differ by $<1 \%$ in the cytochrome $c$ oxidase subunit I gene sequences (the Folmer fragment $)^{19}$. A recent molecular analysis of $S$. contortum from the Håkon Mosby Mud Volcano yielded only evidence for sulphuroxidizing symbionts ${ }^{20}$.

A putative new species of amphipod, which requires further verification, within the Melitidae group is a characteristic member of this community (Fig. 3c,d). These amphipods are found in crevices on the chimneys and in the tube worm fields. They have two main pop-

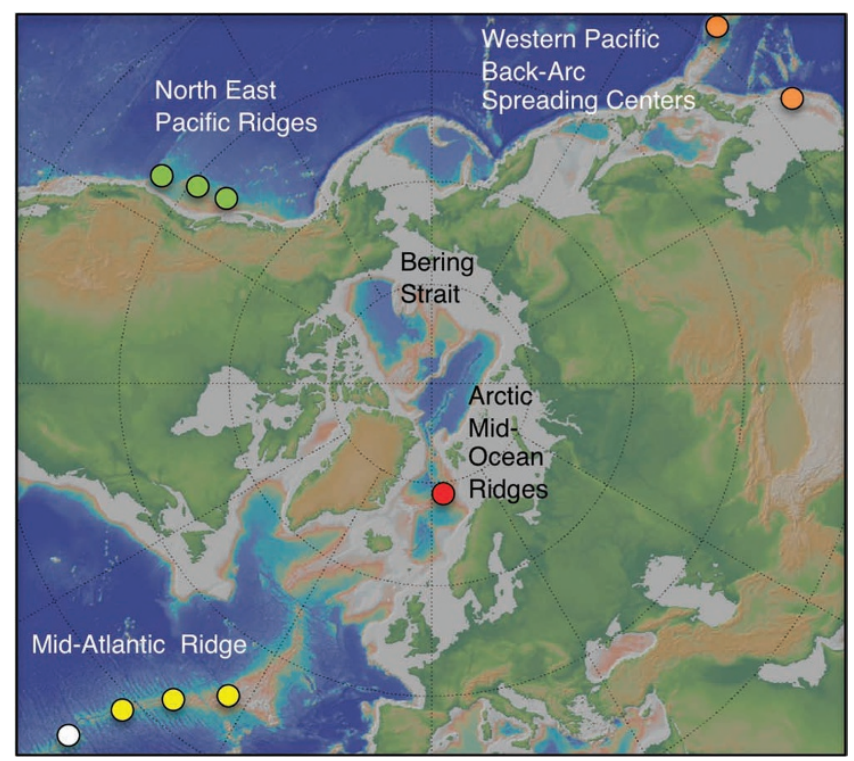

Figure 1 | Location of the Loki's Castle Vent field. A polar projection map showing the Arctic Mid-Ocean Ridge north of Iceland and the location of the Loki's Castle vent field (red dot). The map also shows the locations of the vent fields within the Atlantic and the Pacific ocean hosting vent endemic fauna belonging to different biogeographic provinces: white, Mid-Atlantic Ridge; yellow, Azores; orange, Western Pacific; green, NorthEast Pacific (biogeographic provinces from ref. 11). 

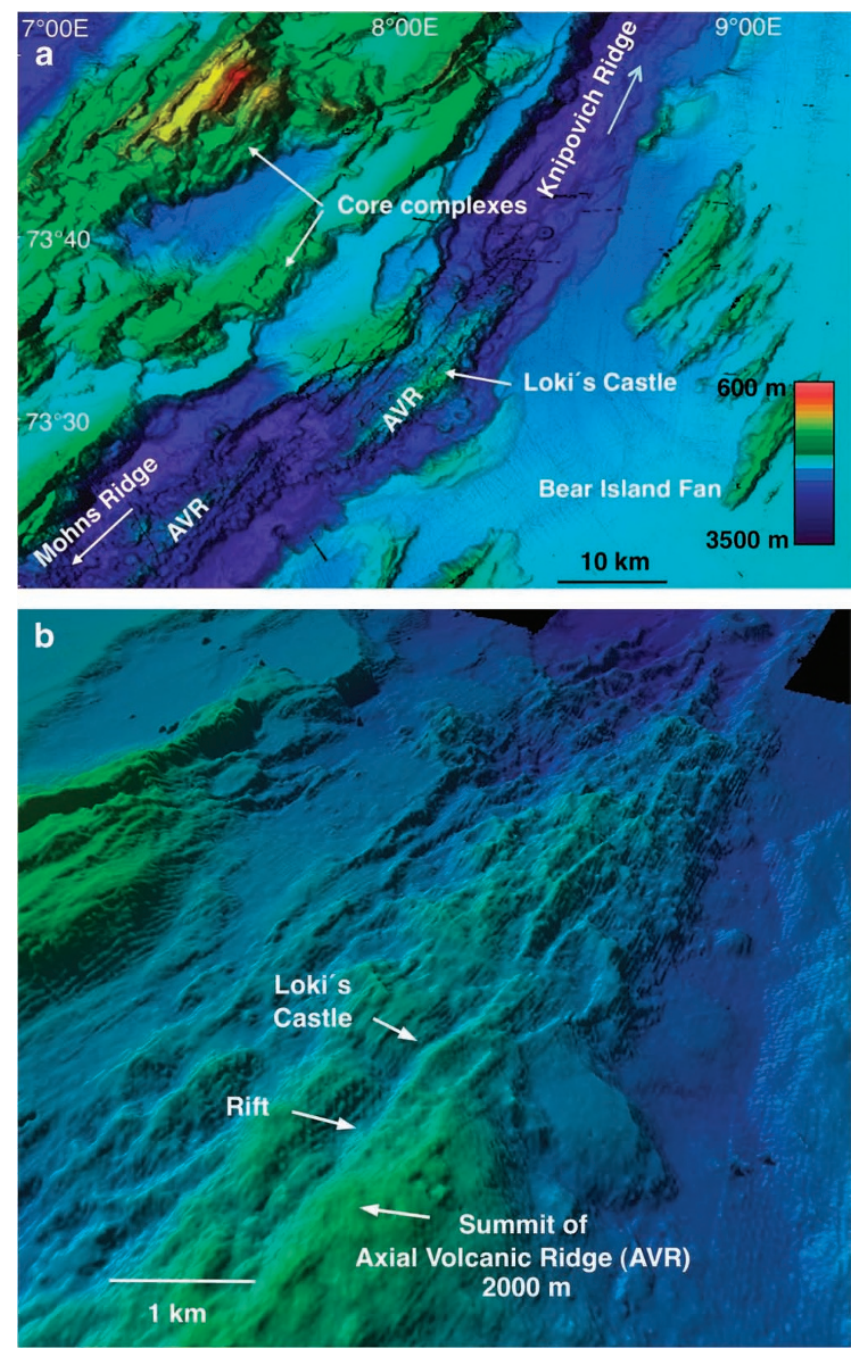

Figure 2 | Geology of the Eastern Mohns Ridge. (a) Map showing: (1) the 30-km-long AVR hosting the vent field; (2) core complexes at the western flank of the ridge; and ( 3 ) the eastern flank that is buried by the distal parts of the Bear Island sedimentary fan, which developed during repeated Arctic glaciations during the last 3 million years. (b) Bathymetry of the AVR and surrounding terrain viewed obliquely from the south. The map shows that the vent field is located next to a rift that runs along the crest of the ridge, where normal faults appears to represent the main channel way for the hydrothermal fluids. ulations of chemoautotrophic gill symbionts (Fig. 3e). A $\delta^{15} \mathrm{~N}$ value of $-5.9 \%$ shows a trophic relationship to microbial populations. A $\delta^{34} \mathrm{~S}$ isotope signature of $+11.9 \%$ is consistent with this, whereas the carbon isotope ratio is less diagnostic $\left(\delta^{13} \mathrm{C}=-23 \% 0\right)$. The new amphipod species seems to represent a local Arctic adaptation to a trophic niche that in the Atlantic Ocean is filled by vent shrimps. The chimney walls are also densely populated by small grazing gastropods Pseudosetia griegi (Fig. 3f) and Skenea spp. P. griegi is also known from the Jan Mayen vent fields and the Nyegga cold seeps ${ }^{13}$. Thick crusts of tube-dwelling polychaetes (Nicomache sp nov.) are found at diffuse venting sites at the base of some chimneys and at the sulphide mound. Similarly, vent-adapted species of Nicomache are known from the Eastern Pacific as far north as the Explorer Ridge ${ }^{21}$. The Stauromedusae Lucernaria bathyphila was found surrounding outlets of moderately warm fluids. Only one other species of this group (Lucernaria janetae) is known from such depths. This was associated with a black smoker vent field at the East-Pacific Rise ${ }^{22}$.

\section{Discussion}

The sheer size of the mound at Loki's Castle documents extensive venting and shows that ultraslow-spreading ridges may host unusually large hydrothermal deposits despite their reduced magmatic heat budget. The longevity of vent fields depends on the size of the heat source and the stability of the conduit. The importance of longlived detachment faults for hydrothermal activity at slow-spreading ridges has recently been recognized ${ }^{23-25}$. The Loki's Castle field shows that long-lived conduits may also form directly at the AVRs (Fig. 4a), probably as a result of the slow plate divergence and the reduced volcanic activity at ultraslow-spreading rates.

Vent fields are less frequent at ultraslow-spreading ridges than at ridges spreading at faster rates. This is related to the magmatic heat being strongly reduced as a result of the lower spreading rates and thinner crust. However, relative to the magmatic heat available, the frequency of hydrothermal vent sites seems to be 2-3 times higher at ultraslow-spreading ridges than at ridges spreading at faster rates ${ }^{4}$. The reason for this is unclear, but tapping of deeper heat sources within the lower crust or upper mantle has been proposed ${ }^{4}$. The Loki's Castle fluids reach $317^{\circ} \mathrm{C}$, with an $\mathrm{EM} \mathrm{SiO}_{2}$ content of up to $16 \mathrm{mmol} \mathrm{kg}^{-1}$. EM chlorinity is around $85 \%$ of seawater suggesting that the fluids have phase separated at depth. The $\mathrm{SiO}_{2}$ and chlorinity contents of vent fluids are pressure and temperature sensitive $e^{26,27}$. The fluid compositions indicate that the rock-water reactions occur around $2 \mathrm{~km}$ below the seafloor (Fig. $4 \mathrm{~b}$ ). This is comparable to the depth of the reaction zones at ridges spreading at a much faster rate $^{27}$. The crustal thickness is estimated to be $4 \pm 0.5 \mathrm{~km}$ at the central Mohns Ridge ${ }^{28}$ (Fig. 4c). This is $2-3 \mathrm{~km}$ less than the average thickness of oceanic crust. Therefore, the depth of the reaction zone

Table 1 | EM compositions of hydrothermal fluids.

\begin{tabular}{|c|c|c|c|c|c|c|c|c|c|c|}
\hline & \multicolumn{3}{|c|}{ João } & \multicolumn{3}{|c|}{ Menorah } & \multicolumn{3}{|c|}{ Camel } & \multirow{2}{*}{$\begin{array}{c}\text { Sleepy } \\
2009\end{array}$} \\
\hline & 2008 & 2009 & 2010 & 2008 & 2009 & 2010 & 2008 & 2009 & 2010 & \\
\hline $\mathrm{pH}$ & 5.52 & 6.06 & 5.60 & 5.52 & 5.66 & 5.57 & 5.50 & 5.77 & 5.62 & 5.90 \\
\hline $\mathrm{EM} \mathrm{NH}_{4}^{+}\left(\mathrm{mmol} \mathrm{kg}^{-1}\right)$ & - & 5.17 & 5.63 & - & 4.77 & 4.68 & - & 5.77 & 6.13 & 4.52 \\
\hline $\mathrm{EM} \mathrm{H}_{2} \mathrm{~S}\left(\mathrm{mmol} \mathrm{kg}^{-1}\right)$ & 4.71 & 3.35 & 4.60 & 4.60 & 2.62 & 3.28 & 4.48 & 3.17 & 4.32 & 3.24 \\
\hline $\mathrm{EM} \mathrm{Na}\left(\mathrm{mmol} \mathrm{kg}^{-1}\right)$ & 383 & 395 & 391 & 388 & 404 & 296 & 386 & 392 & 395 & 404 \\
\hline $\mathrm{EM} \mathrm{K}\left(\mathrm{mmol} \mathrm{kg}^{-1}\right)$ & 34.9 & 34.8 & 33.0 & 34.8 & 36.8 & 24.9 & 35.1 & 34.4 & 32.1 & 36.3 \\
\hline $\mathrm{EM} \mathrm{Ca}\left(\mathrm{mmol} \mathrm{kg}^{-1}\right)$ & 25.9 & 48.7 & 26.7 & 26.0 & 29.4 & 20.2 & 25.6 & 30.6 & 26.3 & 27.7 \\
\hline EM Si $\left(\mathrm{mmol} \mathrm{kg}^{-1}\right)$ & 14.63 & 15.11 & 14.63 & 14.95 & 15.85 & 11.29 & 14.91 & 15.57 & 14.27 & 16.25 \\
\hline $\mathrm{EM} \mathrm{Cl}\left(\mathrm{mmol} \mathrm{kg}^{-1}\right)$ & 502 & 477 & 519 & 500 & 475 & 350 & 496 & 478 & 589 & 475 \\
\hline $\mathrm{EMCO}_{2}\left(\mathrm{mmol} \mathrm{kg}^{-1}\right)$ & 22.28 & 26.01 & - & 25.15 & 25.08 & - & 21.52 & 25.41 & - & 25.82 \\
\hline $\mathrm{EM} \mathrm{H}_{2}\left(\mathrm{mmol} \mathrm{kg}^{-1}\right)$ & 4.76 & 4.81 & - & 4.99 & 4.69 & - & 4.90 & 4.82 & - & 5.50 \\
\hline $\mathrm{EM} \mathrm{CH}_{4}\left(\mathrm{mmol} \mathrm{kg}^{-1}\right)$ & 13.68 & 12.60 & - & 13.30 & 12.52 & - & 15.12 & 13.45 & - & 15.55 \\
\hline
\end{tabular}



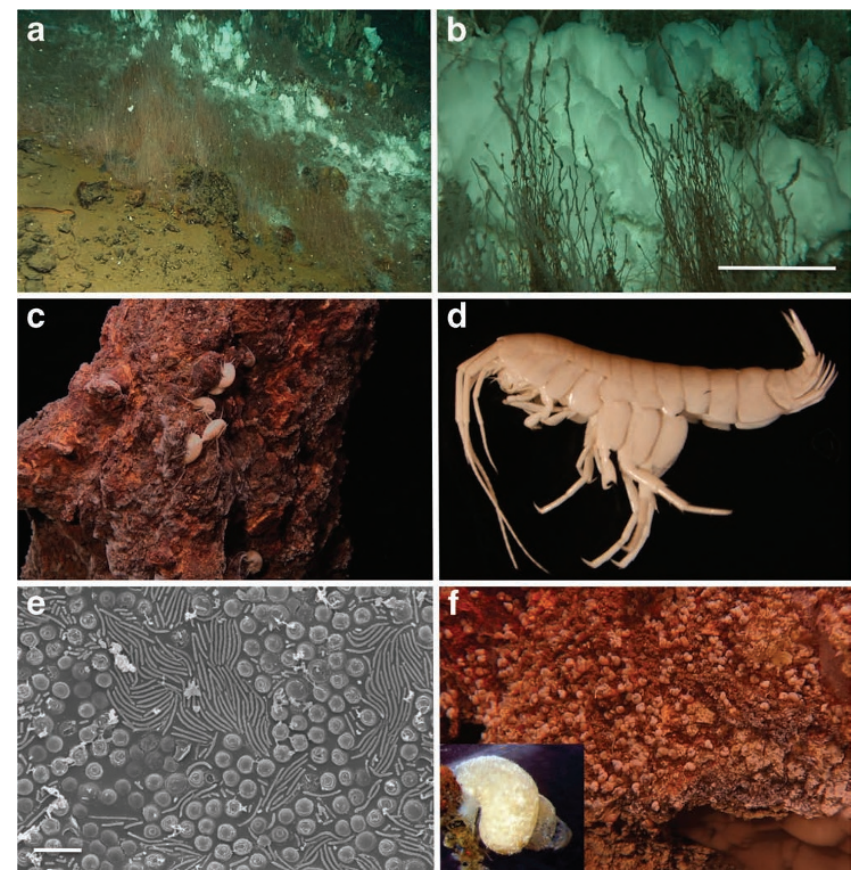

Figure $\mathbf{3}$ | Characteristic invertebrates at the Loki's Castle vent field.

(a) Siboglinid tubeworms (S. contortum) associated with low-temperature diffuse venting at the flank of the hydrothermal mound. White microbial mats and small barite chimneys in the back. (b) Close-up of the siboglinid tube worms in front of white microbial mats. Note the dense populations of small gastropods (P. griegi and Skenea sp.) on the tubes. The scale bar is $5 \mathrm{~cm}$. (c) Amphipods (Melitidae sp. nov.) on a chimney wall. (d) Close-up of a $1.5 \mathrm{~cm}$ juvenile Melitid amphipod. (e) Scanning electron microscopic image of chemoautotrophic gill symbionts from the Melitid amphipod (the scale bar is $3 \mu \mathrm{m}$ ). Based on $16 \mathrm{~S}$ rDNA clone libraries, the two most abundant sequences are affiliated with a gamma proteobacterium, known as a sulphur oxidizer in the bivalve Anodontia fragilis, and sequences with $98 \%$ similarity to an uncultured Methylococcaceae known as a methanotrophic ectosymbiont on the vent crab Shinkaia crosnieri. (f) Small gastropods ( $P$. griegi) populating a chimney wall, with an individual shown as an inset picture ( $\sim 3 \mathrm{~mm}$ across).

is comparable to fast-spreading ridges; however, the fraction of crust cooled convectively by hydrothermal circulation is two times that of vent fields at ridges with normal crustal thickness.

The chemoautotrophic primary production at Loki's Castle supports a vent fauna that is different from that found further south in the Atlantic, where shrimps, large bivalves and crabs are abundant ${ }^{29}$. This lack of typical Atlantic vent fauna indicates either an unfavourable environment or migrational barriers. The ambient water temperature at this Arctic site $\left(-0.7^{\circ} \mathrm{C}\right)$ represents one obvious environmental difference. Iceland defines a land barrier for alongaxis dispersal of fauna, and a southerly flow of deep water from the Arctic represents an additional barrier for deep-water migration northwards. The Arctic Ocean is relatively isolated from the rest of the world's oceans and a high degree of endemism in the deep-water fauna is well documented ${ }^{30,31}$. This endemism clearly extends to the hot-vent environment.

The presence of siboglinid tube worms at Loki's Castle documents interactions between the hot vents and cold-seeps. Several factors may favour such interactions in the Arctic: (1) the general proximity of the ridge system to the continental margins; (2) the unusually high methane concentrations in vent fluids, as documented at Loki's Castle, resulting from interaction between hydrothermal fluids and glacimarine sedimentary deposits; and (3) reduced or arrested methane release from the continental shelf during
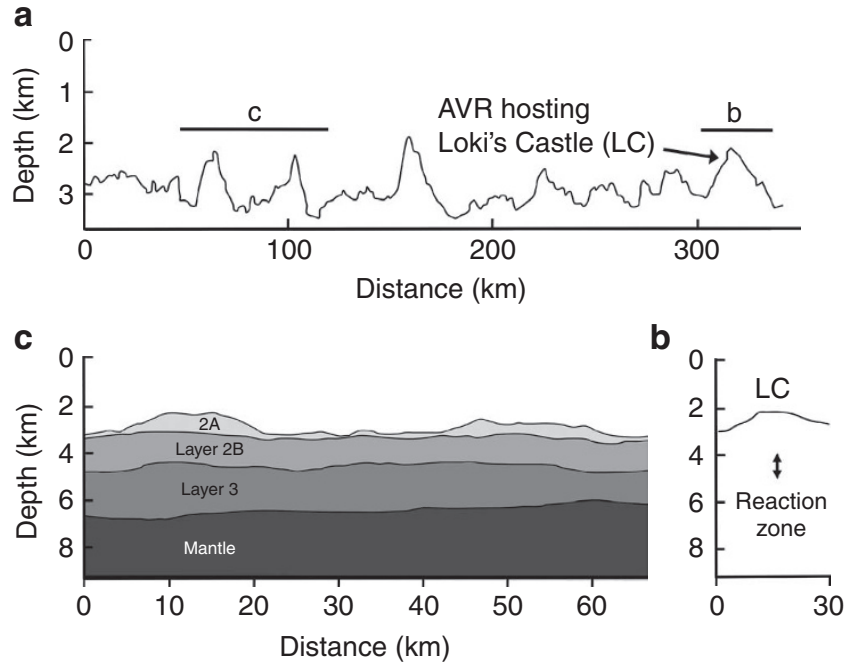

Figure 4 | Depth of reaction zone and lithospheric structure. (a) Alongaxis profile of the central and eastern part of the Mohns Ridge showing the variations in water depth. The profile shows the $30-\mathrm{km}-$ long and $800-\mathrm{m}-$ high AVR hosting the Loki's Castle vent field and the distribution of similar AVRs to the south-west along the ridge. The lines marked $b$ and $c$ show the locations of the along-axis profiles shown in $\mathbf{b}$ and $\mathbf{c}$. (b) Profile of the water depth along the AVR hosting Loki's Castle, and the subsurface depth of the reaction zone, as estimated by EM vent fluid composition using a $\mathrm{Si}-\mathrm{Cl}$ geothermobarometer ${ }^{27}$. The estimated depth of the reaction zone corresponds to the seismic layer 2-3 transition as seen further west at the Mohns Ridge (c). The depth of the reaction zone combined with the crustal thickness suggests that as much as $50 \%$ of the crust is convectively cooled by hydrothermal circulation. (c) Seismic structure across two of the AVRs shown in a (marked c) that document the unusually thin ocean crust $(\sim 4 \mathrm{~km})$ and the boundary between the different oceanic layers within the crust (data from ref. 28 ).

periods of glaciations ${ }^{32}$-rendering the hot vents as safe havens for chemosynthetic organisms during Arctic glaciations.

Some species found at Loki's Castle are closely related to species known from vent sites in the Northern Pacific (for example, the polychaetes Nicomache sp nov. and Amphisamytha sp). Seawater enters the Arctic Ocean either as the North-Atlantic current that bring warm surface water into the Arctic from the south, or as a flow of colder water through the Bering Strait from the Pacific Ocean (Fig. 1). The Bering Strait first opened at $4.8-5.5 \mathrm{Ma}$, and the abrupt appearance of North-Pacific molluscs in the North Atlantic occurred at $3.6 \mathrm{Ma}^{33}$. Our present data therefore indicate that the fauna composition is a result of locally adapted species and of migration from cold seep environments in combination with recent migration of vent fauna into the Arctic Ocean from the Pacific Ocean.

The discovery of this Arctic vent field provides a new opportunity to advance our understanding of the migration of vent fauna and interactions between different chemosynthetic deep-sea environments. The new Arctic vent field also provides the first insight into hydrothermal systems at ultraslow-spreading ridges, which make up $20 \%$ of the global ridge system.

\section{Methods}

Bathymetry. Bathymetry was acquired by R/V G.O. Sars using a Kongsberg Simrad EM300 multibeam echo sounder system. The data processing was done with Kongsberg Simrad Neptune software, the data were gridded to $30 \mathrm{~m}$ cell sizes and were displayed using the Fledermaus software package.

Water column analyses. Potential venting areas were selected based on the bathymetry, and the water column above these areas were searched for signs of venting using a Seabird conductivity/temperature/depth profiler that was equipped 
with a particle sensor (C Star transmissometer), and an Eh-sensor that was kindly provided by Koichi Nakamura (Geol. Surv. of Japan, Agency of Ind. Sci. and Technol).

Plume samples for methane and hydrogen were analysed by a headspace technique in which $100 \mathrm{ml}$ of sample and $40 \mathrm{ml}$ of helium were combined in a $140 \mathrm{ml}$ syringe. The sample was vigorously shaken and allowed to equilibrate until the sample reached room temperature. The analysis was done by gas chromatography using a pulsed discharge detector for hydrogen and a flame ionization detector for methane.

\section{Remotely operated vehicle (ROV) operations and sampling. The vent field} was located and sampled using a Bathysaurus XL remotely operated vehicle (ROV) provided by Argus Remote Systems. Video was acquired using a highdefinition camera, from which the still photos were captured. Fluid samples were collected using 250 and 1,000-ml titanium syringe samplers. Fluids for gas analyses were collected in pre-evacuated titanium gas tight samplers. The vent fauna was sampled by a suction sampler and with a hydraulically operated box sampler.

High-temperature vent fluid analyses. $\mathrm{H}_{2} \mathrm{~S}$ and $\mathrm{NH}_{4}^{+}$as well as $\mathrm{pH}$ were measured onboard. The subsamples analysed for $\mathrm{H}_{2} \mathrm{~S}$ were drawn in a vial and fixed immediately with reagents for the photometric methylene blue method. $\mathrm{NH}_{4}^{+}$analyses were done using the photometric indophenol method. Chloride was analysed onshore by ion chromatography, and magnesium and silica were quantified by inductively coupled plasma optical emission spectrometry. On recovery, the gas tight samplers were connected to a shipboard vacuum line and the gases were extracted, dried and sealed in break-seal glass tubes. Several cuts of each sample were taken and $\mathrm{CO}_{2}, \mathrm{CH}_{4}$ and $\mathrm{H}_{2}$ contents were analysed in shore-based laboratories. The $\mathrm{Mg}$ contents of the different samples provided information on the relative amount of hydrothermal fluid and seawater in the samples taken. The Mg value of the sample was then used to calculate the vent fluid composition (called EM vent fluid compo sition), shown in Table 1.

DNA and stable isotope analyses. The $\mathrm{C}, \mathrm{N}$ and $\mathrm{S}$ isotope compositions of vent fauna taxa were analysed at Institute for Energy Technology (IFE), Norway. Approximately $1 \mathrm{mg}$ of material was used for the $\mathrm{C}$ and $\mathrm{N}$ analyses and $2 \mathrm{mg}$ for the $\mathrm{S}$ analyses. The isotopic measurements were done with a Nu Instrument Horizon, isotope ratio mass spectrometer, and the results were corrected against international standards IAEA-N-1 and IAEA-N-2 $\left(\delta^{15} \mathrm{~N}\right)$, USGS-24 $\left(\delta^{13} \mathrm{C}\right)$, and IAEA-S1 and IAEA-S2 for $\delta^{34} S$ analyses. DNA was extracted using the FastDNA SPIN Kit for Soil following the protocols from the supplier. The Folmer primers were used to amplify a 550-bp region of cytochrome $c$ oxidase subunit I. The $16 \mathrm{SrDNA}$ clone library of gill symbionts in the melitid amphipod was obtained using the primers $\mathrm{B} 338 \mathrm{f}^{34}$ and B1392r (modified from ref. 35) and the Strataclone PCR Cloning Kit from Strategene. Scanning electron microscopic micrographs of gill symbionts were prepared using a ZEIZZ Supra 55VP FE-SEM on critical point-dried and iridium-coated material.

\section{References}

1. Rona, P. A. et al. Black smokers, massive sulfides and vent biota at the MidAtlantic Ridge. Nature 321, 33-37 (1986).

2. Dick, H. J. B. et al. An ultraslow-spreading class of ocean ridge. Nature 426, 405-412 (2003).

3. Michael, P. J. et al. Magmatic and amagmatic seafloor generation at the ultraslow-spreading Gakkel ridge, Arctic Ocean. Nature 423, 956-961 (2003).

4. Baker, E. T. \& German, C. R. On the global distribution of hydrothermal vent fields. in Mid-Ocean Ridges: Hydrothermal Interactions Between the Lithosphere and Oceans (eds German, C. R., Lin, J. \& Parson, L. M.) 245-266 (Geophysical Monograph Series 148, AGU, 2004).

5. German, C. R. et al. Hydrothermal activity along the southwest Indian Ridge. Nature 395, 490-493 (1998).

6. Baker, E. T. et al. Hydrothermal venting in magma deserts: the ultraslowspreading Gakkel and Southwest Indian Ridges. Geochem. Geophys. Geosyst. 5, Q08002 (2004).

7. Edmonds, H. N. et al. Discovery of abundant hydrothermal venting on the ultraslow-spreading Gakkel ridge in the Arctic Ocean. Nature 421, 252-256 (2003).

8. Van Dover, C. L. et al. Biogeography and ecological setting of Indian Ocean hydrothermal vents. Science 294, 818 (2001).

9. Hessler, R. R. \& Lonesdale, P. F. Biogeography of Mariana Trough hydrothermal vent communities. Deep Sea Res. A 38, 18-199 (1991).

10. Tyler, P. A. \& Young, C. M. Reproduction and dispersal at vents and cold seeps J. Mar. Biol. Assoc. UK 79, 193-208 (1999).

11. Van Dover, C. L. et al. Evolution and biogeography of deep-sea vent and seep invertebrates. Science 295, 1253-1257 (2002)

12. Pedersen, R. B. et al. in Diversity of Hydrothermal Systems on Slow-Spreading Ocean Ridges (eds Rona, P. A. et al.) 67-89 (Geophysical Monograph Series 188, AGU, 2010)

13. Schander, C. et al. The fauna of hydrothermal vents on the Mohn Ridge (North Atlantic). Mar. Biol. Res. 6, 155-171 (2010).
14. Tarasov, V. G. et al. Deep-sea and shallow-water hydrothermal vent communities: two different phenomena? Chem. Geol. 224, 5-39 (2005).

15. Humphris, S. E. et al. The internal structure of an active sea-floor massive sulfide deposit. Nature 377, 713-716 (1995)

16. Charlou, J. L. et al. Geochemistry of high $\mathrm{H} 2$ and $\mathrm{CH} 4$ vent fluids issuing from ultramafic rocks at the Rainbow hydrothermal field $\left(36^{\circ} 14^{\prime} \mathrm{N}, \mathrm{MAR}\right)$. Chem. Geol. 191, 345-359 (2002).

17. Proskurowski, G. et al. Low temperature volatile production at the Lost City Hydrothermal Field, evidence from a hydrogen stable isotope geothermometer Chem. Geol. 229, 331-343 (2006).

18. Kelley, D. S. et al. A serpentine-hosted ecosystem: the lost city hydrothermal field. Science 207, 1428-1434 (2005).

19. Hilário, A. High diversity of frenulates (Polychaeta: Siboglinidae) in the Gulf of Cadiz mud volcanoes: a DNA taxonomy analysis. Deep Sea Res. Part I 57, 143-150 (2010).

20. Lösekann, T. et al. Endosymbioses between bacteria and deep-sea siboglinid tubeworms from an Arctic Cold Seep (Hakon Mosby Mud Volcano, Barents Sea). Environ. Microbiol. 10, 3237-3254 (2008).

21. Blake, J. A. \& Desbruyères, D. Nicomache arwidssoni Blake, 1985 'bamboo worm, in Handbook of Deep-Sea Hydrothermal Vent Fauna, 2nd edition (eds Desbruyères, D., Segonzac, M. \& Bright, M.) 266 (Denisia 18, Biologiezentrum Linz, Austria, 2006)

22. Collins, A. G. \& Daly, M. New deepwater species of Stauromedusae, Lucernaria janetae (Cnidaria, Staurozoa, Lucernariidae), and a preliminary investigation of stauromedusan phylogeny based on nuclear and mitochondrial rDNA data. Biol. Bull. 208, 221-330 (2005).

23. Kelley, D. S. et al. An off-axis hydrothermal vent field near the Mid-Atlantic Ridge at 30N. Nature 412, 145-149 (2001).

24. Boschi, C. et al. Mass transfer and fluid flow during detachment faulting and development of an oceanic core complex, Atlantis Massif $\left(30^{\circ} \mathrm{N}\right)$, Geochem. Geophys. Geosyst. 7, Q01004 (2005).

25. McCaig, A. M. et al. Oceanic detachment faults focus very large volumes of black smoker fluids. Geology 35, 935-938 (2007).

26. Von Damm, K. L. et al. Quartz solubility in hydrothermal seawater: an experimental study and equation describing quartz solubility for up to $0.5 \mathrm{M}$ $\mathrm{NaCl}$ solutions. Am. J. Sci. 291, 977-1007 (1991).

27. Fontaine, F. J. et al. A Si-Cl geothermobarometer for the reaction zone of hightemperature, basaltic-hosted mid ocean ridge hydrothermal systems. Geochem. Geophys. Geosyst. 10, Q05009 (2009).

28. Klingelhöfer, F. et al. Crustal structure of a super-slow spreading centre: a seismic refraction study of Mohns Ridge, $72^{\circ}$ N. Geophys. J. Int. 141, 509-526 (2000).

29. Van Dover, C. L. Milestones in the discovery of hydrothermal vent fauna, in Handbook of Deep-Sea Hydrothermal Vent Fauna, 2nd edition (eds Desbruyères, D., Segonzac, M. \& Bright, M.) 13-25 (Denisia 18, Biologiezentrum Linz, Austria, 2006).

30. Svavarsson, J., Stromberg, J.- O. \& Brattegard, T. The deep-sea Asellota (Isopoda, Crustacea) fauna of the northern seas: species composition, distributional patterns and origin. J. Biogeogr. 20, 537-555 (1993).

31. Stuart, C. T. \& Rex, M. A. Bathymetric patterns of deep-sea gastropod species diversity in 10 basins of the Atlantic Ocean and Norwegian Sea. Mar. Ecol. Evol. Perspect. 30, 164-180 (2009).

32. Kvenvolden, K. A. in Gas Hydrates: Relevance to World Margin Stability and Climate Change Vol. 137 (eds Henriet, J. -P. \& Mienert, J.) 9-30 (Geol. Soc. Lond., Spec. Publ., 1998).

33. Marincovich, L. Central American paleogeography controlled Pliocene Arctic Ocean molluscan migrations. Geology 28, 551-554 (2000).

34. Lane, D. J. et al. in Nucleic Acid Techniques in Bacterial Systematics (eds Stackenbrandt, E. \& Goodfellow, M.) 115-148 (John Wiley, 1991).

35. Amann, R. et al. Phylogenetic identification and in situ detection of individual microbial cells without cultivation. Microbiol. Rev. 59, 143-169 (1995)

\section{Acknowledgments}

We thank the Captain and crew of the R/V G.O. Sars and the operators of the ROV Bathysaurus for their invaluable assistance at sea. We thank shipboard and shorebased technical and engineering staffs of the University of Bergen and Institute of Marine Research for assistance with the acquisition of data. Jon Anders Kongsrud, Ken Halanych, Christoffer Schander, Tore Høisæter, Allen Collins and Anne Helene Tandberg are thanked for the help with taxonomy, and Solveig Hoem for the help with DNA sequencing. This work has been supported by the Research Council of Norway through Centre for Geobiology, by the ESF-EUROMARC programme through the H2DEEP project, and by the Norwegian Academy of Science and Letters. We also thank three anonymous reviewers for their helpful reviews of the manuscript.

\section{Author contributions}

All authors participated and contributed to the sampling and data acquisition during the H2DEEP-08 cruise when the Loki's Castle vent field was discovered. The cruise was lead by R.B.P., with H.T.R., I.H.T., M.D.L., F.J.A.S.B. and G.L.F-G. as co-principal investigators. R.B.P. has been responsible for the acquisition of bathymetry and ROV 
operations; H.T.R. for taxonomy and fauna analyses; I.H.T., T.B. and K.F. for vent fluid analyses; M.D.L. and G.L.F-G. for gas sampling and analyses; F.J.A.S.B. and R.F. for sulphide sampling and analyses; and S.L.J. for quality check of DNA data. R.B.P. wrote the bulk of the text with contributions from H.T.R., I.H.T., M.D.L., F.J.A.S.B. and G.L.F.G.

\section{Additional information}

Competing financial interests: The authors declare no competing financial interests.
Reprints and permission information is available online at http://npg.nature.com/ reprintsandpermissions/

How to cite this article: Pedersen, R.B. et al. Discovery of a black smoker vent field and vent fauna at the Arctic Mid-Ocean Ridge. Nat. Commun. 1:126 doi: 10.1038/ncomms1124 (2010).

License: This work is licensed under a Creative Commons Attribution-NonCommercialShare Alike 3.0 Unported License. To view a copy of this license, visit http:// creativecommons.org/licenses/by-nc-sa/3.0/ 